\title{
Pine needle oil induces G2/M arrest of HepG2 cells by activating the ATM pathway
}

\author{
BING QIU $^{1 *}$, WEI JIANG ${ }^{2 *}$, WENLIANG QIU ${ }^{1}$, WENLING MU ${ }^{1}$, YUJING QIN ${ }^{1}$, \\ YONGCUI ZHU ${ }^{1}$, JIANYING ZHANG ${ }^{1}$, QINGYI WANG ${ }^{3}$, DONGJIE LIU ${ }^{1}$ and ZHANGYI QU ${ }^{4}$ \\ ${ }^{1}$ Department of Gastroenterology, Heilongjiang Provincial Hospital, Harbin, Heilongjiang 150036; \\ ${ }^{2}$ Department of Gastroenterology, The First Affiliated Hospital of Jiamusi University, Jiamusi, Heilongjiang 154002, \\ P.R. China; ${ }^{3}$ Center for Computational and Integrative Biology, Massachusetts General Hospital, \\ Harvard Medical School, Boston, MA 02114, USA; ${ }^{4}$ Department of Hygienic Microbiology, \\ Public Health College, Harbin Medical University, Harbin, Heilongjiang 150081, P.R. China
}

Received January 6, 2017; Accepted August 23, 2017

DOI: $10.3892 /$ etm.2017.5648

\begin{abstract}
Over the last two decades, inducing DNA damage of cancer cells by natural medicines has become a research hotspot in the field of cancer treatment. Although various natural medicines have anticancer effects, very few studies have been conducted to explore the anti-cancer effect of pine needle oil. In the present study, the role of pine needle oil in inducing G2/M arrest in HepG2 cells was investigated. The data revealed that pine needle oil could induce DNA damage in a dose-dependent manner. In the pine needle oil-treated HepG2 cells, the protein levels of phosphorylated (p)-ataxia-telangiectasia mutated (ATM), $\gamma$-H2A histone family, member X, p-p53, p-checkpoint kinase 2 and p-cell division cycle $25 \mathrm{C}$ were evidently increased, indicating that pine needle oil facilitated G2/M arrest in HepG2 cells through the ATM pathway. In response to the treatment with pine needle oil, ATM was activated in HepG2 cells, which subsequently phosphorylated downstream targets and induced G2/M arrest. In summary, the data of the present study indicated that pine needle oil induces $\mathrm{G} 2 / \mathrm{M}$ arrest in $\mathrm{HepG} 2$ cells by facilitating ATM activation.
\end{abstract}

Correspondence to: Dr Bing Qiu, Department of Gastroenterology, Heilongjiang Provincial Hospital, 82 Zhongshan Road, Harbin, Heilongjiang 150036, P.R. China

E-mail: bingqiu07@163.com

Professor Zhangyi Qu, Department of Hygienic Microbiology, Public Health College, Harbin Medical University, 157 Baojian Road, Harbin, Heilongjiang 150081, P.R. China

E-mail: hmu635@126.com

${ }^{*}$ Contributed equally

Key words: pine needle oil, DNA damage, G2/M arrest, ataxia-telangiectasia mutated

\section{Introduction}

Liver cancer is one of the most common types of malignant tumor and is also one of the leading causes of cancer mortality, particularly in East Asia and Sub-Saharan Africa (1). Liver cancer has become an increasing threat to human health. The number of liver cancer mortalities is evidently increasing worldwide each year, and the 5-year survival rate is $<9 \%$ (2). Additionally, the most common therapeutic options for liver cancer are surgery and chemotherapy. Therefore, it is necessary to develop novel effective drugs or preventive therapies against human hepatoma (3). Pine tree is evergreen and needle-leafed, and its various parts, including the leaf, cones, cortices and pollen, have been used as a health-promoting food and complementary therapy $(4,5)$. Pine needle has been demonstrated to contain active components that present biological effects in several studies (6-9). As a pine needle extract, pine needle oil has demonstrated anticancer effects and has been used as an anticancer agent in traditional Chinese medicine (10).

Genomic stability is monitored throughout the cell cycle. DNA damages may result from errors during replication, by-products of metabolism, general toxic drugs or ionizing radiation (11). There are two major cell cycle checkpoints, namely G1/S and G2/M, that ensure proper cell cycle progression (12). As a critical factor to maintain genomic stability, G2/M cell cycle arrest occurs when DNA is damaged, which provides an opportunity for DNA repair and prevents cells from entering mitosis $(13,14)$. As a serine/threonine protein kinase, ataxia-telangiectasia mutated (ATM) phosphorylates several key proteins that activate the DNA damage checkpoint, leading to cell cycle arrest, DNA repair or apoptosis (15). Several of these target proteins, including p53, checkpoint kinase 2 (CHK2), breast cancer 1, nibrin 1 and $\mathrm{H} 2 \mathrm{~A}$ histone family, member X (H2AX), are tumor suppressors (13,16-18). Therefore, dysregulation of ATM may cause defective repair of DNA damage, which results in the development of various types of cancer $(19,20)$. The present study examined the effect of pine needle oil on the proliferation of HepG2 cells and the possible molecular mechanism underlying this effect. 


\section{Materials and methods}

Materials. Pine needle oil [dissolved in dimethyl sulfoxide (DMSO), $\leq 0.1 \%$ ], RNase and propidium iodide (PI) solution were purchased from Sigma-Aldrich (Merck KGaA, Darmstadt, Germany). Anti- $\gamma$-H2AX (cat no. 05636; 1:1,000) antibody was purchased from EMD Millipore Billerica, MA, USA), ATM (cat no. 2873; 1:500), p-ATM (cat no. 13050; 1:1,000), p-p53 (S15; cat no. 9286; 1:1,000), p-CDC25C (S216; cat no. 4901; 1:500) p-CHK2 (T68; cat no. 2661; 1:1,000) and CHK2 (cat no. 2662; 1:1,000) antibodies were purchased from Cell Signaling Technology, Inc., (Danvers, MA, USA). CDC25C (cat no. sc-327; 1:1,000), $\beta$-actin (cat no. sc-47778; 1:1,000), anti-H2AX (cat no. sc-54606; 1:200), p53 (cat no. sc-98; 1:500) antibodies, goat anti-rabbit (cat no. sc-2030; 1:3,000) and anti-mouse secondary (cat no. sc-2031; 1:3,000) antibodies were purchased from Santa Cruz Biotechnology, Inc., (Dallas, TX, USA). Protein extraction solution kit was purchased from Beijing SBS Genetech Co., Ltd., (Beijing, China). Dulbecco's modified Eagle's medium and bovine serum albumin were purchased from Gibco (Thermo Fisher Scientific, Inc., Waltham, MA, USA). The HepG2 cell line was purchased from the China Center for Type Culture Collection of Wuhan University (Wuhan, China). This cell line was originally thought to be a hepatocellular carcinoma, but is now known to be a hepatoblastoma cell line (21).

Cell culture. HepG2 cells were cultured in 1x Eagle's Minimum Essential medium (cat no. 10-009-CV; Corning Incorporated, Corning, NY, USA) supplemented with $10 \%$ FBS (cat no. 35-011-CV; Corning Incorporated). Fresh culture medium was replenished every $2 \sim 3$ days. Cells were cultured at $37^{\circ} \mathrm{C}$ with $5 \% \mathrm{CO}_{2}$. Cell splitting was performed as follows: The cell monolayer was rinsed with 1x PBS followed by the addition of $0.05 \%$ Trypsin-EDTA solution to cover the dish bottom and then cells were incubated at $37^{\circ} \mathrm{C}$ for $\sim 5 \mathrm{~min}$.

Flow cytometry. The HepG2 cells were treated with pine needle oil $(0.16$ and $5.12 \mathrm{mg} / \mathrm{ml})$ or DMSO $(0.16$ and $5.12 \mathrm{mg} / \mathrm{ml})$ at different concentrations for $48 \mathrm{~h}$ at $37^{\circ} \mathrm{C}$ and then collected and washed with phosphate-buffered saline (PBS) twice. The cells were fixed with $70 \%$ ice-cold alcohol at $4^{\circ} \mathrm{C}$ for $>1 \mathrm{~h}$, rinsed in ice-cold PBS twice, and suspended in $3 \mathrm{ml}$ PBS-containing ribonuclease (100 $\mu \mathrm{g} / \mathrm{l}$; cat no. R6148-25ML, Sigma-Aldrich; Merck KGaA). Following this, HepG2 cells were incubated at $37^{\circ} \mathrm{C}$ for $30 \mathrm{~min}$ and then stained with PI $(50 \mu \mathrm{g} / \mathrm{l})$ for $30 \mathrm{~min}$ in the dark. Subsequently, the percentages of cells at different phases of the cell cycle were analyzed by flow cytometry. The excitation wavelength utilized in the measurement was $488 \mathrm{~nm}$ (probe: PE-Texas Red, Biolegend, Inc. San Diego, CA, USA). Images were captured using BD FACSDiva software (v8; BD Biosciences, San Jose, CA, USA).

Western blotting. HepG2 cells treated with pine needle oil or DMSO were collected by centrifugation at $150 \mathrm{x} g$ at room temperature for $10 \mathrm{~min}$ and resuspended with lysis buffer at a density of $2 \times 10^{6}$ cells $/ \mathrm{ml}$ followed by protein extraction using a protein extraction solution kit. Following this, the protein concentration was determined by a bicinchoninic acid assay and proteins were denatured at $95^{\circ} \mathrm{C}$ for $10 \mathrm{~min}$. A total of
$50 \mu \mathrm{g}$ of protein per lane was loaded into the $12 \%$ SDS-PAGE and the proteins were transferred onto a polyvinylidene difluoride (PVDF) membrane, followed by blocking with TBST containing 5\% BSA (cat no. BP1605-100; Thermo Fisher Scientific, Inc.) for $1 \mathrm{~h}$ at room temperature. Subsequently, the membrane was incubated with the primary antibodies overnight at $4^{\circ} \mathrm{C}$ and the PVDF membrane was washed three times with Tris-buffered saline containing 0.1\% Tween-20 (TBST) prior to incubating with the secondary antibody at room temperature for $1 \mathrm{~h}$. Following incubation, the membrane was washed with TBST three times again and developed using an enhanced chemiluminescence method (Clarity Western ECL Substrate; cat no. 1705060; Bio-Rad Laboratories, Inc., Hercules, CA, USA) (22-24).

Immunofluorescence staining. HepG2 cells were treated with different doses of pine needle oil $(0.16$ and $5.12 \mathrm{mg} / \mathrm{ml})$ or DMSO (vehicle control; 1:1,000) for $48 \mathrm{~h}$. Cells were fixed with pre-chilled $\left(-20^{\circ} \mathrm{C}\right)$ acetone-methanol $(50: 50 \%)$ for $15 \mathrm{~min}$. The cells were washed with 1X PBS and then blocked with $5 \% \mathrm{BSA}$ for $1 \mathrm{~h}$ at room temperature. Anti- $\gamma \mathrm{H} 2 \mathrm{AX}$ antibody (cat no. 05636; 1:200; EMD Millipore) diluted in $5 \% \mathrm{BSA}$ was added onto the slides and incubated at $4^{\circ} \mathrm{C}$ overnight ( $15 \mathrm{~h})$. The slides were then washed twice with $1 \mathrm{x}$ PBS (with $0.2 \%$ Triton), followed by incubation with donkey anti-mouse secondary antibody (cat no. A-21203; 1:5,000; Thermo Fisher Scientific, Inc.) for $1 \mathrm{~h}$ at room temperature. The cells were then mounted with anti-fade reagent containing 4',6-diamidino-2-phenylindole. A fluorescent microscope (Carl Zeiss AG, Oberkochen, Germany) was used to image the samples at a magnification of $\mathrm{x} 400(25)$.

Statistical analysis. Data was analyzed using SPSS 18.0 (SPSS Inc., Chicago, IL, USA). Data analyses were performed using one-way analysis of variance followed by Tukey's test. Error bars represented the mean \pm standard error of the mean. $P<0.05$ was considered to indicate a statistically significant difference.

\section{Results}

Pine needle oil induces cell cycle arrest at the G2/M phase in HepG2 cells. In order to examine whether pine needle oil induced G2/M arrest and contributed to the inhibition of tumor growth, HepG2 cells were used as a cell model, which was treated with pine needle oil at different concentrations $(0.16$ and $5.12 \mathrm{mg} / \mathrm{ml})$ in the general culture condition. DMSO was used as a vehicle control. As depicted in Fig. 1, the proportion of cells at the G2/M phase evidently increased in the pine needle oil-treated group compared with the control group. In addition, the number of HepG2 cells at the G2/M phase was significantly increased in the group treated with higher concentration of pine needle oil $(5.12 \mathrm{mg} / \mathrm{ml})$ compared with the group treated with a lower concentration of pine needle oil $(0.16 \mathrm{mg} / \mathrm{ml})(\mathrm{P}<0.05$; Table I). By contrast, the proportion of the cell population at the G0/G1 phase was markedly decreased in the group treated with higher concentration of pine needle oil $(5.12 \mathrm{mg} / \mathrm{ml})$ compared with the group treated with a lower concentration of pine needle oil. The data in Fig. 1 and Table I indicate that pine needle oil facilitated G2/M arrest of HepG2 cells in a dose-dependent manner. 
DMSO

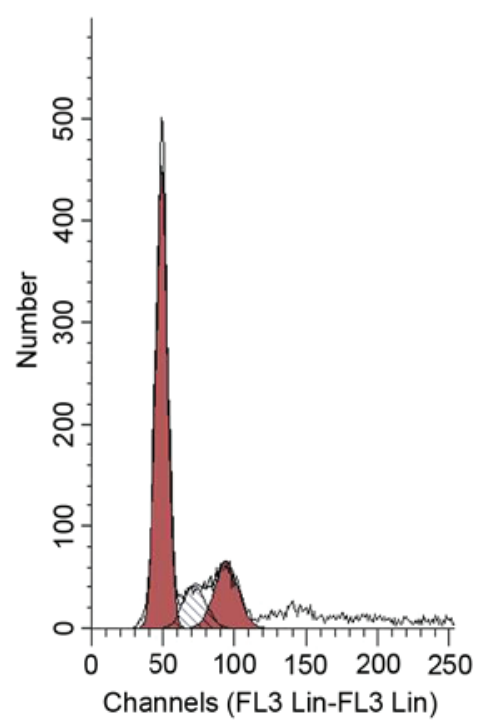

Pine needle oil $(0.16 \mathrm{mg} / \mathrm{ml})$

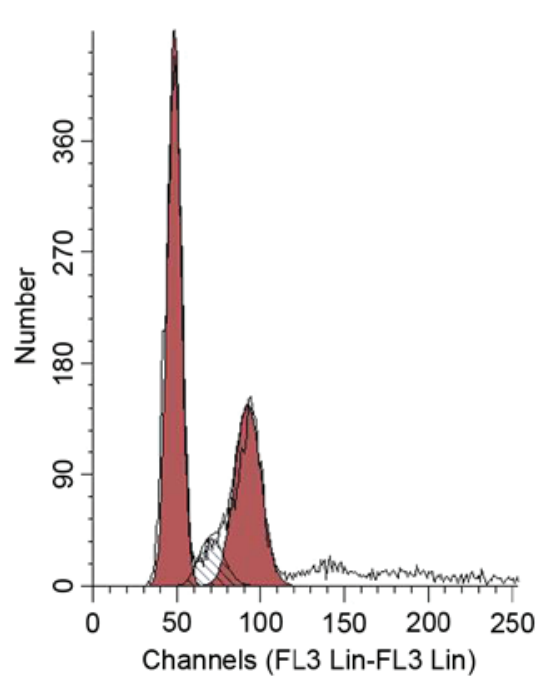

Pine needle oil $(5.12 \mathrm{mg} / \mathrm{ml})$



Figure 1. Treatment with pine needle oil induces cell cycle arrest at the G2/M phase in HepG2 cells. The HepG2 cells were treated with pine needle oil at different concentrations and DMSO as a vehicle control for $48 \mathrm{~h}$, followed by flow cytometry analysis to determine the phase distribution in the cell cycle. The data revealed that pine needle oil induced G2/M arrest in a dose-dependent manner. DMSO, dimethyl sulfoxide.

Pine needle oil induces G2/M arrest by activating the ATM pathway. To evaluate whether cell cycle-related proteins, including p53, ATM, H2AX and CHK2, were involved in the pine needle oil-induced G2/M arrest in HepG2 cells, the expression levels of these proteins were assessed by western blotting. As demonstrated in Fig. 2, following incubation with pine needle oil at various concentrations $(0.00,0.01,0.16,5.12$ and $40.96 \mathrm{mg} / \mathrm{ml}$ ), p-ATM (S1981), p-CHK2 (T68), p-p53, p53 and $\gamma$-H2AX expression levels in HepG2 cells were markedly upregulated. Furthermore, the higher concentration of pine needle oil administrated, the greater the upregulation of these proteins, which indicated that the activation of these proteins by pine needle oil occurred in a dose-dependent manner. These results demonstrate that $\mathrm{G} 2 / \mathrm{M}$ arrest was induced by pine needle oil by activation of the ATM pathway in HepG2 cells.

Pine needle oil induces the expression of $\gamma-H 2 A X$ in the nucleus of HepG2 cells. To further confirm the upregulation of $\gamma$-H2AX in HepG2 cells following treatment with pine needle oil, immunostaining was performed with specific antibodies against $\gamma-\mathrm{H} 2 \mathrm{AX}$. As presented in Fig. 3, without pine needle oil treatment, $\gamma$-H2AX was not detectable in the nuclei of HepG2 cells. Following pine needle oil treatment at different concentrations, $\gamma$-H2AX (red) was evidently upregulated in the nuclei in a dose-dependent manner (Fig. 3).

\section{Discussion}

Liver cancer is one of the most commonly diagnosed types of cancer worldwide and the third most common cause of cancer mortality $(26,27)$. This disease is responsible for $\sim 1$ million mortalities per year (28). Thus far, the most recognized therapeutic strategies for liver cancer are surgery and chemotherapy. Although tremendous achievements have been made in the treatment of liver cancer over the last two decades, the therapeutic effects of current options of treatment remain unsatisfactory and it is essential to seek more effective treatment methods to improve the prognosis of liver cancer (29). Natural medicine, particularly traditional Chinese medicine, is one of the most attractive therapeutic methods used to treat various types of cancer. Recently, efforts have been largely focused on exploring effective natural medicine for the treatment of liver cancer (30-33). Pine needle oil is one such natural medicine that may serve an important role in the treatment of liver cancer $(10,34,35)$. It is extracted and purified from the leaf of the Pinus, a member of the Pinaceae family (36). Previous studies have revealed that pine needle oil has antioxidant, antimicrobial and anticancer activities $(34,37)$. However, these studies need to be further validated, as the ability to inhibit the abnormal proliferation and induce apoptosis in human tumor cell lines could be applied to develop more effective anticancer drugs.

During the development of an organism, several types of biological processes are fundamental, including cell proliferation, division and deformation, apoptosis and necrosis (38). Regulation of the cell cycle involves processes crucial to cell survival, including the monitoring and repair of genetic damages, as well as the prevention of uncontrolled cell division (39). The molecular events that control the cell cycle are ordered and directional. Once certain abnormal activities occur at certain phases of the cell cycle, cells may enter pathological processes, such as programed (40-42). A prevalent view is that uncontrolled cell cycle events are responsible for the initiation and development of tumors. The destruction of cell cycle regulation is a typical feature in the majority of cancer cells $(43,44)$. Therefore, in order to control cancer, it is critical to correct the mistakes in cell cycle regulation, and the checkpoints provide the opportunity for self-healing of cells prior to mitosis. The G2/M checkpoint, also known as the DNA damage checkpoint, ensures that the cell undergoes all the necessary changes during the $\mathrm{S}$ and $\mathrm{G} 2$ phases and is 
Table I. Cell cycle analysis of HepG2 cells treated with pine needle oil.

Percentage of cells in each cell cycle phase in each treatment group

\begin{tabular}{lccc}
\cline { 2 - 4 } $\begin{array}{l}\text { Cell cycle } \\
\text { phase }\end{array}$ & $\begin{array}{c}\text { Dimethyl } \\
\text { sulfoxide }\end{array}$ & $\begin{array}{c}\text { Pine needle oil } \\
(0.16 \mathrm{mg} / \mathrm{ml})\end{array}$ & $\begin{array}{c}\text { Pine needle oil } \\
(5.12 \mathrm{mg} / \mathrm{ml})\end{array}$ \\
\hline $\mathrm{G} 1$ & $61.5 \pm 5.2$ & $47.4 \pm 3.9^{\mathrm{a}}$ & $43.2 \pm 1.3^{\mathrm{b}, \mathrm{c}}$ \\
$\mathrm{S}$ & $21.5 \pm 4.4$ & $17.2 \pm 2.4^{\mathrm{a}}$ & $11.3 \pm 1.6^{\mathrm{b}, \mathrm{c}}$ \\
$\mathrm{G} 2 / \mathrm{M}$ & $17.0 \pm 1.1$ & $35.4 \pm 3.4^{\mathrm{a}}$ & $45.5 \pm 2.1^{\mathrm{b}, \mathrm{c}}$ \\
\hline
\end{tabular}

Data were produced from three independent experiments and are presented as the mean \pm standard error of the mean. ${ }^{a} \mathrm{P}<0.05$ low dose pine needle oil group vs. DMSO group; ${ }^{b} \mathrm{P}<0.05$ high dose pine needle oil group vs. DMSO group; ${ }^{~} \mathrm{P}<0.05$ high dose pine needle oil group vs. low dose pine needle oil group.

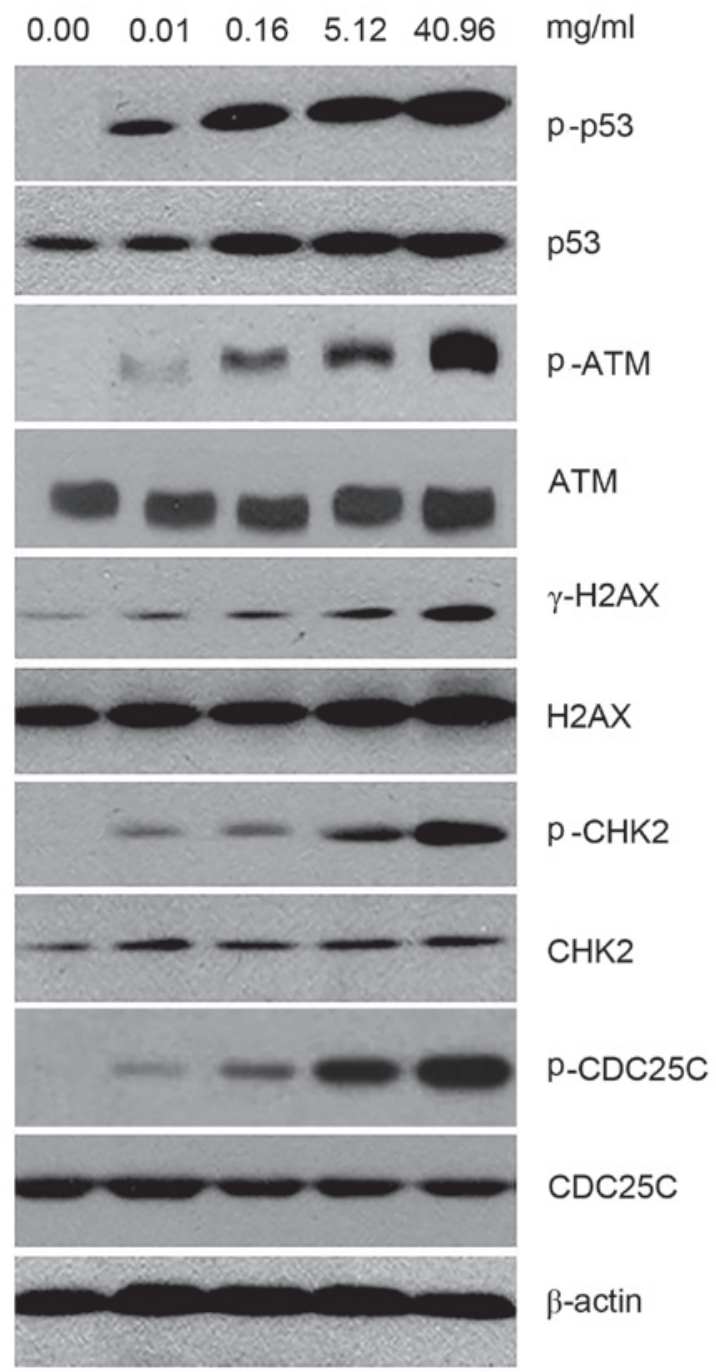

Figure 2. Key proteins involved in the ATM pathway are activated by treatment with pine needle oil. HepG2 cells treated with dimethyl sulfoxide or pine needle oil at various concentrations were lysed and analyzed by western blotting. p-ATM (S1981), p-CHK2 (T68), p-p53, p53 and $\gamma$-H2AX were evidently upregulated in HepG2 cells following treatment with pine needle oil. Additionally, $\beta$-actin was used as a loading control. p, phosphorylated ATM, ataxia-telangiectasia mutated; H2AX, H2A histone family; CHK2, checkpoint kinase 2 ; CDC25C, cell division cycle $25 \mathrm{C}$.

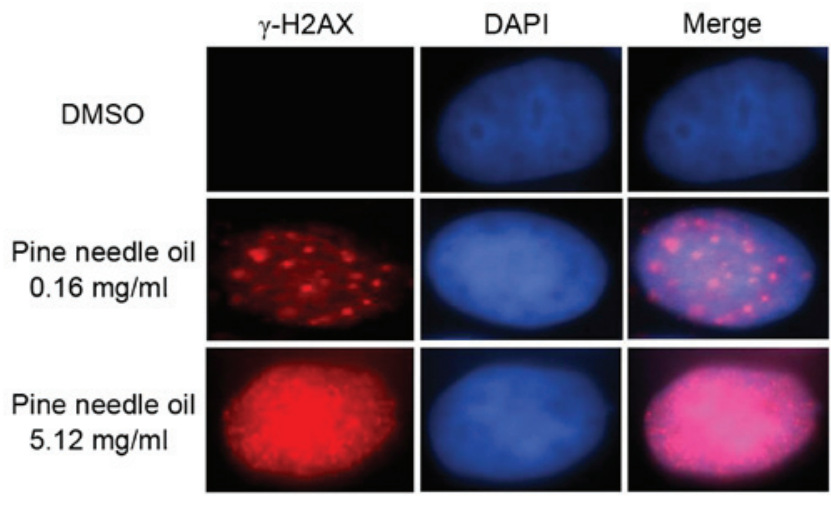

Figure 3. Treatment with pine needle oil enhances the nuclear expression of $\gamma$-H2AX. The nucleus was stained with DAPI. The treatment of pine needle oil markedly enhanced the nuclear expression of $\gamma-\mathrm{H} 2 \mathrm{AX}$ (red) in HepG2 cells in a dose-dependent manner. H2AX, H2A histone family, member X; DMSO, dimethyl sulfoxide; DAPI, 4',6-diamidino-2-phenylindole. Magnification, $\mathrm{x} 400$.

ready for cell division $(45,46)$. Thus, inducing $\mathrm{G} 2 / \mathrm{M}$ arrest is an effective strategy of controlling the proliferation of cancer cells. As demonstrated in the present study, the proportion of HepG2 cells at the G2/M phase was markedly elevated when the cells were treated with pine needle oil. The results indicated that pine needle oil induced cell cycle arrest at the G2/M checkpoint in HepG2 cells and inhibited cancer cell growth by interfering with mitotic progression.

DNA damage naturally and frequently occurs due to endogenous and exogenous cellular processes $(47,48)$. It is a major problem for life since cells must make large investments in DNA repair processes to maintain genomic integrity. The failure of self-healing of DNA damage or the accumulation of DNA damage-related factors may lead to abnormal cell growth that may result in the formation and development of diseases, such as cancer $(49,50)$. It was reported that DNA damage may activate ATM $(51,52)$. Furthermore, the activation of ATM subsequently facilitates the activation or phosphorylation of other key proteins that are able to detect DNA damage. Once these downstream proteins perceive the signals of DNA damage, they may trigger programed processes to complete the repair of damaged DNA, induce apoptosis or promote cell cycle arrest $(53,54)$. Therefore, the ATM pathway serves an important role in maintaining genomic stability and preventing tumorigenesis. Several targets of ATM, including H2AX, p53 and CHK2, are tumor suppressors $(55,56)$. In response to DNA double-strand breaks (DSB), H2AX may be phosphorylated on serine 139 by ATM. Furthermore, the phosphorylated product of $\mathrm{H} 2 \mathrm{AX}$, namely $\gamma-\mathrm{H} 2 \mathrm{AX}$, is a sensitive target for DSB in cells $(57,58)$. As a tumor suppressor, p53 has been described as 'the guardian of the genome' due to its role in conserving stability by preventing genomic mutations. Previous studies have revealed that p53 has anticancer function through various mechanisms and is involved in cell cycle arrest in HepG2 cells (59-65). As a protein that also acts as a tumor suppressor, CHK2 regulates cell division in a way to prevent cells from dividing too rapidly or in an uncontrolled manner $(66,67)$. In 1999, genetic variations of CHK2 were revealed to be associated with inherited cancer susceptibility (68). Specifically, Thr68 of CHK2 may be phosphorylated and activated by 
DNA damage-activated ATM (69). The activated CHK2 may then phosphorylate downstream targets, including cell division cycle (CDC)25C phosphatases, which may prevent the cell from entering mitosis by dephosphorylating and activating cyclin B-bound $\mathrm{CDC} 2$ (70). By preventing mutated or damaged DNA from being passed into daughter cells, CHK2 stops tumors from developing $(71,72)$.

Treatment of cancer by traditional Chinese medicine has become an important therapeutic strategy for cancer patients (73-78). As a traditional Chinese medicine, pine needle oil has been used for numerous years. It was reported that pine needle oil had antioxidant and antimicrobial activities (37). In addition, scientists have revealed that pine needle oil possesses anticancer effects in various cancer cells, such as breast cancer cells (79). Previously, Wei et al (34) demonstrated that pine needle oil could induce the apoptosis of HepG2 cells. However, besides the data that reveals that pine needle oil could induce apoptosis and activity changes of telomerase in the HepG2 cell line (34), no further studies have been conducted. Therefore, it is crucial to conduct more in-depth investigations to comprehensively understand the mechanisms underlying the anticancer effect of pine needle oil. The present study indicated that pine needle oil induces G2/M cell cycle arrest and presents its anticancer effect by activating the ATM pathway. The data demonstrated that the expression of p-ATM (S1981), p-CHK2 (T68), p-p53, $\gamma$-H2AX and $\mathrm{CDC} 25 \mathrm{C}$ all increased in a dose-dependent manner in the HepG2 cells that were treated with pine needle oil, implying that pine needle oil induces $\mathrm{G} 2 / \mathrm{M}$ arrest by activating the ATM pathway. When the HepG2 cells were treated with pine needle oil, the damaged DNA activated the ATM by autophosphorylation of ATM (S1981), which subsequently facilitated the activation of CHK2, H2AX and p53 by phosphorylation. The activation of these downstream proteins further transfers the signals to other related proteins, which results in cell cycle arrest. Furthermore, it is well recognized that DNA damage may induce the phosphorylation of ATM $(80,81)$. The confocal laser scanning microscopy data of the present study demonstrated that treatment with pine needle oil could increase p-ATM in the nucleus of HepG2 cells, indicating that DNA damage induced the activation of ATM by phosphorylation in the nucleus. Based on the data provided in the present study, a conclusion may be drawn that pine needle oil induces $\mathrm{G} 2 / \mathrm{M}$ cell cycle arrest by activating the ATM signaling pathways, inhibits proliferation, and balances proliferation and apoptosis in HepG2 cells.

\section{Acknowledgements}

The present study was supported by a grant from the Foundation of Excellent Returned Overseas Students of Heilongjiang in China (grant no. 2015-424) and the Postdoctoral Fellowship of Heilongjiang Province of China (grant no. LBH-Z15152).

\section{References}

1. Della Corte C, Triolo M, Iavarone M and Sangiovanni A: Early diagnosis of liver cancer: An appraisal of international recommendations and future perspectives. Liver Int 36: 166-176, 2016.

2. Chen JG and Zhang SW: Liver cancer epidemic in China: Past, present and future. Semin Cancer Biol 21: 59-69, 2011.
3. Midorikawa Y, Sugiyama Y and Aburatani H: Molecular targets for liver cancer therapy: From screening of target genes to clinical trials. Hepatol Res 40: 49-60, 2010.

4. Sakagami H, Yoshihara M, Fujimaki M, Wada C, Komatsu N, Nakashima H, Murakami T and Yamamoto N: Effect of pine seed shell extract on microbial and viral infection. In Vivo 6: 13-16, 1992.

5. Ni Z, Mu Y and Gulati O: Treatment of melasma with pycnogenol. Phytother Res 16: 567-571, 2002.

6. Politeo O, Skocibusic M, Maravic A, Ruscic M and Milos M: Chemical composition and antimicrobial activity of the essential oil of endemic Dalmatian black pine (Pinus nigra ssp. dalmatica). Chem Biodivers 8: 540-547, 2011.

7. Lee JS, Kim HG, Lee HW, Han JM, Lee SK, Kim DW, Saravanakumar A and Son CG: Hippocampal memory enhancing activity of pine needle extract against scopolamine-induced amnesia in a mouse model. Sci Rep 5: 9651, 2015.

8. Wang C, He L, Yan M, Zheng GY and Liu XY: Effects of polyprenols from pine needles of Pinus massoniana on ameliorating cognitive impairment in a D-galactose-induced mouse model. Age (Dordr) 36: 9676, 2014.

9. Liao CL, Chen CM, Chang YZ, Liu GY, Hung HC, Hsieh TY and Lin CL: Pine (Pinus morrisonicola Hayata) needle extracts sensitize GBM8901 human glioblastoma cells to temozolomide by downregulating autophagy and $\mathrm{O}(6)$-methylguanine-DNA methyltransferase expression. J Agric Food Chem 62: 10458-10467, 2014.

10. Chen WQ, Xu B, Mao JW, Wei FX, Li M, Liu T, Jin XB and Zhang LR: Inhibitory effects of $\alpha$-pinene on hepatoma carcinoma cell proliferation. Asian Pac J Cancer Prev 15: 3293-3297, 2014.

11. O'Neill JP: DNA damage, DNA repair, cell proliferation, and DNA replication: How do gene mutations result? Proc Natl Acad Sci USA 97: 11137-11139, 2000.

12. Agarwal ML, Agarwal A, Taylor WR and Stark GR: p53 controls both the G2/M and the G1 cell cycle checkpoints and mediates reversible growth arrest in human. Proc Natl Acad Sci USA 92: 8493-8497, 1995

13. Selvarajah J, Elia A, Carroll VA and Moumen A: DNA damage-induced $\mathrm{S}$ and $\mathrm{G} 2 / \mathrm{M}$ cell cycle arrest requires mTORC2-dependent regulation of Chk1. Oncotarget 6: 427-440, 2015.

14. Hua KF, Liao PC, Fang Z, Yang FL, Yang YL, Chen YL, Chiu YC, Liu ML, Lam Y and Wu SH: Generation of reactive oxygen species by polyenylpyrroles derivatives causes DNA damage leading to G2/M arrest and apoptosis in human oral squamous cell carcinoma cells. PLoS One 8: e67603, 2013.

15. Vecchio D and Frosina G: Targeting the ataxia telangiectasia mutated protein in cancer therapy. Curr Drug Targets 17: 139-153, 2016.

16. Cosentino C, Grieco D and Costanzo V: ATM activates the pentose phosphate pathway promoting anti-oxidant defence and DNA repair. EMBO J 30: 546-555, 2011.

17. Goodarzi AA, Noon AT, Deckbar D, Ziv Y, Shiloh Y, Löbrich M and Jeggo PA: ATM signaling facilitates repair of DNA double-strand breaks associated with heterochromatin. Mol Cell 31: 167-177, 2008.

18. Enns L, Rasouli-Nia A, Hendzel M, Marples B and Weinfeld M: Association of ATM activation and DNA repair with induced radioresistance after low-dose irradiation. Radiat Prot Dosimetry 166: 131-136, 2015.

19. Bay JO, Uhrhammer N, Stoppa-Lyonnet D and Hall J: Role of the ATM gene in genetic predisposition to cancer. Bull Cancer 87: 29-34, 2000 (In French).

20. Brunet J, Gutiérrez-Enriquez S, Torres A, Bérez V, Sanjosé S, Galceran J, Izquierdo A, Menéndez JA, Gumà J and Borràs J: ATM germline mutations in Spanish early-onset breast cancer patients negative for BRCA1/BRCA2 mutations. Clin Genet 73: 465-473, 2008.

21. López-Terrada D, Cheung SW, Finegold MJ and Knowles BB: Hep G2 is a hepatoblastoma-derived cell line. Hum Pathol 40: 1512-1515, 2009.

22. Li Y, He Y, Qiu Z, Zhou B, Shi S, Zhang K, Luo Y, Huang Q and Li W: CRTC2 and PROM1 expression in non-small cell lung cancer: Analysis by Western blot and immunohistochemistry. Tumour Biol 35: 11719-11726, 2014.

23. Xu H and Zhang S: Scutellarin-induced apoptosis in HepG2 hepatocellular carcinoma cells via a STAT3 pathway. Phytother Res 27: 1524-1528, 2013.

24. Zou CG and Banerjee R: Tumor necrosis factor-alpha-induced targeted proteolysis of cystathionine beta-synthase modulates redox homeostasis. J Biol Chem 278: 16802-16808, 2003. 
25. Wei F, Xie Y, Tao L and Tang D: Both ERK1 and ERK2 kinases promote $\mathrm{G} 2 / \mathrm{M}$ arrest in etoposide-treated MCF7 cells by facilitating ATM activation. Cell Signal 22: 1783-1789, 2010.

26. Ryder S, Rizzi P, Karani J and Williams R: Therapy for hepatocellular-carcinoma (review). Int J Oncol 6: 1113-1122, 1995.

27. Liu Y, Wu C, Wang Y, Wen S, Wang J, Chen Z, He Q and Feng D Loss of plexin-B3 in hepatocellular carcinoma. Exp Ther Med 9: $1247-1252,2015$.

28. Torre LA, Bray F, Siegel RL, Ferlay J, Lortet-Tieulent J and Jemal A: Global cancer statistics, 2012. CA Cancer J Clin 65: 87-108, 2015

29. Mokdad AA, Singal AG and Yopp AC: JAMA PATIENT PAGE. Treatment of liver cancer. JAMA 315: 100, 2016

30. Khan F, Khan TJ, Kalamegam G, Pushparaj PN, Chaudhary A, Abuzenadah A, Kumosani T, Barbour E and Al-Qahtani M: Anti-cancer effects of Ajwa dates (Phoenix dactylifera L.) in diethylnitrosamine induced hepatocellular carcinoma in Wistar rats. BMC Complement Altern Med 17: 418, 2017.

31. Yao W, Ba Q, Li X, Li H, Zhang S, Yuan Y, Wang F, Duan X, Li J, Zhang W and Wang H: A natural CCR2 antagonist relieves Tumor-associated Macrophage-mediated immunosuppression to produce a therapeutic effect for liver cancer. EBioMedicine 22 58-67, 2017.

32. Mao J, Wang D, Wang Z, Tian W, Li X, Duan J, Wang Y, Yang H, You L, Cheng Y, et al: Combretastatin A-1 phosphate, a microtubule inhibitor, acts on both hepatocellular carcinoma cells and tumor-associated macrophages by inhibiting the Wnt/ $\beta$-catenin pathway. Cancer Lett 380: 134-143, 2016.

33. Kant R, Yen $\mathrm{CH}$, Lu CK, Lin YC, Li JH and Chen YM: Identification of 1,2,3,4,6-Penta-O-galloyl- $\beta$-d-glucopyranoside as a Glycine N-Methyltransferase enhancer by High-throughput screening of natural products inhibits hepatocellular carcinoma. Int J Mol Sci 17: pii: E669, 2016.

34. Wei FX, Li MY, Song YH and Li HZ: Apoptosis and activity changes of telomerase induced by essential oil from pine needles in HepG2 cell line. Zhong Yao Cai 31: 1197-1200, 2008 (In Chinese).

35. Chen W, Liu Y, Li M, Mao J, Zhang L, Huang R, Jin X and Ye L: Anti-tumor effect of $\alpha$-pinene on human hepatoma cell lines through inducing G2/M cell cycle arrest. J Pharmacol Sci 127 332-338, 2015

36. Shen C, Duan W, Cen B and Tan J: Comparison of chemical components of essential oils in needles of Pinus massoniana Lamb and Pinus elliottottii Engelm from Guangxi. Se Pu 24 619-624, 2006 (In Chinese).

37. Zeng WC, Zhang Z, Gao H, Jia LR and He Q: Chemical composition, antioxidant, and antimicrobial activities of essential oil from pine needle (Cedrus deodara). J Food Sci 77: C824-C829, 2012.

38. Peter ME: Programmed cell death: Apoptosis meets necrosis Nature 471: 310-312, 2011.

39. Nowsheen $\mathrm{S}$ and Yang ES: The intersection between DNA damage response and cell death pathways. Exp Oncol 34 243-254, 2012

40. Galderisi U, Jori FP and Giordano A: Cell cycle regulation and neural differentiation. Oncogene 22: 5208-5219, 2003.

41. Chen XY, Wang Z, Li B, Zhang YJ and Li YY: Pim-3 contributes to radioresistance through regulation of the cell cycle and DNA damage repair in pancreatic cancer cells. Biochem Biophys Res Commun 473: 296-302, 2016

42. Lee PS, Fang J, Jessop L, Myers T, Raj P, Hu N, Wang C, Taylor PR, Wang J, Khan J, et al: RAD51B activity and cell cycle regulation in response to DNA damage in breast cancer cell lines. Breast Cancer (Auckl) 8: 135-144, 2014.

43. Elmore S: Apoptosis: A review of programmed cell death Toxicol Pathol 35: 495-516, 2007.

44. Kastan MB and Bartek J: Cell-cycle checkpoints and cancer. Nature 432: 316-323, 2004

45. Stark GR and Taylor WR: Control of the G2/M transition. Mol Biotechnol 32: 227-248, 2006.

46. Stark GR and Taylor WR: Analyzing the G2/M checkpoint Methods Mol Biol 280: 51-82, 2004.

47. Zhao H, Tanaka T, Halicka HD, Traganos F, Zarebski M, Dobrucki J and Darzynkiewicz Z: Cytometric assessment of DNA damage by exogenous and endogenous oxidants reports aging-related processes. Cytometry A 71: 905-914, 2007.

48. Mullaart E, Lohman PH, Berends F and Vijg J: DNA damage metabolism and aging. Mutat Res 237: 189-210, 1990

49. Lord CJ and Ashworth A: The DNA damage response and cancer therapy. Nature 481: 287-294, 2012.
50. Jackson SP and Bartek J: The DNA-damage response in human biology and disease. Nature 461: 1071-1078, 2009.

51. Bakkenist CJ and Kastan MB: DNA damage activates ATM through intermolecular autophosphorylation and dimer dissociation. Nature 421: 499-506, 2003.

52. Kurz EU and Lees-Miller SP: DNA damage-induced activation of ATM and ATM-dependent signaling pathways. DNA Repair (Amst) 3: 889-900, 2004.

53. Norbury CJ and Zhivotovsky B: DNA damage-induced apoptosis Oncogene 23: 2797-2808, 2004.

54. Zhou BB and Elledge SJ: The DNA damage response: Putting checkpoints in perspective. Nature 408: 433-439, 2000.

55. Squatrito M, Brennan CW, Helmy K, Huse JT, Petrini JH and Holland EC: Loss of ATM/Chk2/p53 pathway components accelerates tumor development and contributes to radiation resistance in gliomas. Cancer Cell 18: 619-629, 2010.

56. Kang J, Ferguson D, Song H, Bassing C, Eckersdorff M, Alt FW and Xu Y: Functional interaction of H2AX, NBS1, and p53 in ATM-dependent DNA damage responses and tumor suppression. Mol Cell Biol 25: 661-670, 2005.

57. Kinner A, Wu W, Staudt C and Iliakis G: Gamma-H2AX in recognition and signaling of DNA double-strand breaks in the context of chromatin. Nucleic Acids Res 36: 5678-5694, 2008.

58. Kuo LJ and Yang LX: Gamma-H2AX-a novel biomarker for DNA double-strand breaks. In Vivo 22: 305-309, 2008.

59. Yang G, Zhou X, Wang J, Zhang W, Zheng H, Lu W and Yuan J: MEHP-induced oxidative DNA damage and apoptosis in HepG2 cells correlates with p53-mediated mitochondria-dependent signaling pathway. Food Chem Toxicol 50: 2424-2431, 2012.

60. Park SY, Lee SM, Ye SK, Yoon SH, Chung MH and Choi J Benzo[a]pyrene-induced DNA damage and p53 modulation in human hepatoma HepG2 cells for the identification of potential biomarkers for PAH monitoring and risk assessment. Toxicol Lett 167: 27-33, 2006

61. Song X, Li L, Shi Q, Lehmler HJ, Fu J, Su C, Xia X, Song E and Song Y: Polychlorinated Biphenyl quinone metabolite promotes p53-Dependent DNA damage checkpoint activation, S-Phase cycle arrest and extrinsic apoptosis in human liver hepatocellular carcinoma HepG2 cells. Chem Res Toxicol 28: 2160-2169, 2015.

62. Zhao M, Guo T, Wang M, Zhao Q, Liu Y, Sun X, Wang H and Hou Y: The course of uncarinic acid E-induced apoptosis of HepG2 cells from damage to DNA and p53 activation to mitochondrial release of cytochrome c. Biol Pharm Bull 29: 1639-1644, 2006

63. Zhou SM, Jiang LP, Geng CY, Cao J and Zhong LF: Patulin-induced oxidative DNA damage and p53 modulation in HepG2 cells. Toxicon 55: 390-395, 2010.

64. Qu K, Lin T, Wei J, Meng F, Wang Z, Huang Z, Wan Y, Song S, Liu S, Chang H, et al: Cisplatin induces cell cycle arrest and senescence via upregulating P53 and P21 expression in HepG2 cells. Nan Fang Yi Ke Da Xue Xue Bao 33: 1253-1259, 2013.

65. Wang H, Ye Y, Chui JH, Zhu GY, Li YW, Fong DW and Yu ZL: Oridonin induces G2/M cell cycle arrest and apoptosis through MAPK and p53 signaling pathways in HepG2 cells. Oncol Rep 24: 647-651, 2010.

66. Collins H, Calvo S, Greenberg K, Forman Neall L and Morrison S: Information needs in the precision medicine era: How genetics home reference can help. Interact J Med Res 5: e13, 2016.

67. Huang H, Hu M, Zhao R, Li P and Li M: Dihydromyricetin suppresses the proliferation of hepatocellular carcinoma cells by inducing $\mathrm{G} 2 / \mathrm{M}$ arrest through the $\mathrm{Chk} 1 / \mathrm{Chk} 2 / \mathrm{Cdc} 25 \mathrm{C}$ pathway. Oncol Rep 30: 2467-2475, 2013.

68. Bell DW, Varley JM, Szydlo TE, Kang DH, Wahrer DC Shannon KE, Lubratovich M, Verselis SJ, Isselbacher KJ, Fraumeni JF, et al: Heterozygous germ line hCHK 2 mutations in Li-Fraumeni syndrome. Science 286: 2528-2531, 1999.

69. Cai Z, Chehab NH and Pavletich NP: Structure and activation mechanism of the CHK2 DNA damage checkpoint kinase. Mol Cell 35: 818-829, 2009.

70. Nilsson I and Hoffmann I: Cell cycle regulation by the $\mathrm{Cdc} 25$ phosphatase family. Prog Cell Cycle Res 4: 107-114, 2000.

71. Nevanlinna $\mathrm{H}$ and Bartek J: The CHEK 2 gene and inherited breast cancer susceptibility. Oncogene 25: 5912-5919, 2006.

72. Mitchell JA, Fomous $C$ and Fun J: Challenges and strategies of the Genetics Home Reference. J Med Libr Assoc 94: 336-342, 2006.

73. Li X, Yang G, Li X, Zhang Y, Yang J, Chang J, Sun X, Zhou X, Guo Y, Xu Y, et al: Traditional Chinese medicine in cancer care: A review of controlled clinical studies published in chinese. PLoS One 8: e60338, 2013. 
74. Nie J, Zhao C, Deng LI, Chen J, Yu B, Wu X, Pang P and Chen X: Efficacy of traditional Chinese medicine in treating cancer. Biomed Rep 4: 3-14, 2016.

75. Zhang $\mathrm{C}$ and $\mathrm{Xu} \mathrm{X}$ : Advancement in the treatment of diminished ovarian reserve by traditional Chinese and Western medicine. Exp Ther Med 11: 1173-1176, 2016.

76. Zhao T, Pan H, Feng Y, Li H and Zhao Y: Petroleum ether extract of Chenopodium album L. prevents cell growth and induces apoptosis of human lung cancer cells. Exp Ther Med 12: 3301-3307, 2016

77. Su CC: Tanshinone IIA potentiates the efficacy of 5-FU in Colo205 colon cancer cells in vivo through downregulation of P-gp and LC3-II. Exp Ther Med 3: 555-559, 2012.

78. Tai Y, Sun YM, Zou X, Pan Q, Lan YD, Huo Q, Zhu JW, Guo F, Zheng CQ, Wu CZ and Liu H: Effect of Polygonatum odoratum extract on human breast cancer MDA-MB-231 cell proliferation and apoptosis. Exp Ther Med 12: 2681-2687, 2016.
79. Hoai NT, Duc HV, Thao do T, Orav A and Raal A: Selectivity of Pinus sylvestris extract and essential oil to estrogen-insensitive breast cancer cells Pinus sylvestris against cancer cells. Pharmacogn Mag 11 (Suppl 2): S290-S295, 2015.

80. Blackford AN and Jackson SP: ATM, ATR, and DNA-PK: The Trinity at the Heart of the DNA Damage Response. Mol Cell 66: 801-817, 2017.

81. Paull TT: Mechanisms of ATM activation. Annu Rev Biochem 84: 711-738, 2015.

(i) $($ This work is licensed under a Creative Commons Attribution-NonCommercial-NoDerivatives 4.0 International (CC BY-NC-ND 4.0) License. 